\title{
Review of Literature on Competencies and Orientation of Entrepreneurs
}

\author{
Indika Priyantha Kaluarachchige ${ }^{1}$, Mohd Shukri Ab Yajid $^{2}$,Ali Khatibi ${ }^{3}$ and \\ S. M. Ferdous Azam ${ }^{4}$ \\ 1 Management \& Science University (MSU),indikapri@gmail.com \\ 2 Management \& Science University (MSU) \\ 3 Management \& Science University (MSU) \\ 4 Management \& Science University (MSU)
}

\section{ABSTRACT}

Entrepreneurship is well established concept in the literature. Organizations such as small and medium enterprises need to improve their entrepreneurial skills to achieve their goals successfully. Each person has exclusive entrepreneurial competencies and entrepreneurial orientation. Entrepreneurial competencies are the tactically important resources of a business. So far, researchers have investigated different kinds of entrepreneurial competencies namely, analytical, commitment, conceptual, decision making, ethical, human, innovative, knowledge, learning, networking, operational, opportunity, organizing, personal, relationship, social responsibility, strategic, technical competencies etc. But, six competencies such as conceptual competency, strategic competency, opportunity competency, learning competency, personal competency, networking competency and ethical competency are well documented in the literature. Entrepreneurial orientation is one of the most regularly applied organizational level construct in entrepreneurship research. As per the literature, entrepreneurial orientation is represented by five dimensions namely innovativeness, risk-taking, autonomy, pro-activeness and competitive aggressiveness. But, three dimensions such as innovativeness, Risk-taking and pro-activeness are well documented in the literature. Impact of entrepreneurship on organizational performance is a most popular research area all over the world. Both Entrepreneurial competencies and entrepreneurial orientation affect the success of business ventures as per the literature. The success of entrepreneurship depends upon the entrepreneurial competencies of entrepreneurs. A number of studies have been conducted on the relationship between entrepreneurial orientation and organizational performance as well. Most scholars have found a positive impact of entrepreneurial orientation also on firm performance. Many countries have investigated the influence of entrepreneurship on organizational performance. As per the literature, good entrepreneurial studies are still lacking in developing countries. Entrepreneurship is regarded as one of the key development initiative in every country. Therefore, future research needs to expand the field of entrepreneurship in any country, especially in developing countries.

Key words:Entrepreneurship, Entrepreneurial Competencies, Entrepreneurial Orientation

Corresponding Author:Kaluarachchige, I.P. 


\section{INTRODUCTION TO ENTREPRENEURSHIP}

Entrepreneurship is one of the key development activity which leads to employment, economic growth innovation and competitiveness (Sajeena, 2020). The development of firm level entrepreneurship concept has shown the result since the beginning of the 21 st century because it has gained wider recognition and is applicable to all types of industry, organization type and age of the company (Nason et al., 2015; Bierwerth et al., 2015). Many researchers mentioned the importance of strategic management with entrepreneurial approach in the process of formulation and implementation of corporate strategy in the era of the 21 st century (Dewi et al., 2017). An entrepreneur is a person who develops and grows the enterprise over innovative and creative actions, through the introduction of new products or services and through the improvement of existing production or service methods (Tehseen and Ramayah, 2015). Each person has exclusive entrepreneurial orientation and entrepreneurial competencies which are hard to be followed by competitors due to the ambiguity of their origins and embeddedness (Tehseen and Ramayah, 2015). Bahari, Yunus and Jabar (2017), establish a meaningful association between entrepreneurial competencies and entrepreneurial orientation toward the success of business ventures.

Small and medium enterprises have been considered as the cornerstone of the business environment in every country, a principal driver of economic development and progress (Qamruzzaman\&Jianguo, 2018). Organizations like small and medium enterprises need to improve their entrepreneurial skills through various motivational strengthening, training, and workshops and mentoring will have an innovative, creative, risk-taking spirit in decisions (Sulistyo\&Ayuni, 2020). Small and medium-sized enterprises are also directly associated to the economic wellbeing of their entrepreneurs. Hence, the growth and superior performance of firms depend on the priority of most entrepreneurs (Rosli and Abdullah, 2015). Entrepreneurial behaviour is more critical to attain and maintain a sustainable competitive advantage (Nwachukwu, Chladkova and Pavel Zufan, 2017). The entrepreneurship literature has emphasized the entrepreneurs' role for the enterprise success in small and medium business field (Tehseen and Ramayah, 2015). The impact of entrepreneurship on organizational performance has been well-established in the literature (Monteiro, Soares and Rua, 2019).

While small enterprises are vital in tackling the challenges of high poverty rates, high unemployment and income inequality, small enterprises are suffering from poor performance and high failure rates in many countries (Bamiatzi\&Kirchmaier, 2014). According to Hyder\&Lussier, (2016), small businesses performance and issues are crucial and need to be addressed in developing countries. It is still needed a lot of empirical evidence in implementing the concept of entrepreneurship (Rauch, 2015). Future research needs to expand the field of small and medium enterprises which involves several important factors in driving the creation of innovation for SME managers in achieving competitive advantage (Sulistyo\&Ayuni, 2020).

\section{ENTREPRENEURIAL COMPETENCIES}

Competence is the ability to apply or use a set of allied knowledge, skills and abilities necessary to perform critical work role or tasks successfully in a defined work environment (CareerOneStop, 2014). Entrepreneurial competencies are the strategically important resources of businesses, and many valuable benefits can be derived from these valuable competencies (Omar et al., 2016; Tehseen\&Ramayah, 2015). The success of entrepreneurship depends upon the entrepreneurial competencies of entrepreneurs (Sajeena, 2020).

Several studies have focused on entrepreneurial competency using a variety of terms, such as characteristics, competencies, traits, qualities (Bacigalupo et al., 2016; Badal, 2014; Kaur \&Bains, 2013; Pofeldt, 2014). A competency cluster is a construct consisting of various 
common competencies. Many researchers have recognized key competency clusters (Boyatzis, 1982; Spencer \& Spencer, 1993; Man, 2001; Zwemstra, 2006; Ahmad, 2007; Nakhata, 2007; Rathna\&Vijaya, 2009; Mitchelmore\& Rowley, 2010).

Mitchelmore and Rowley (2010) developed a cluster based competency framework. The framework consists of four clusters such as entrepreneurial, business/ management, human relations and conceptual/ relationship. Zwemstra (2006) made a framework that is based on seven competency clusters such as managerial behaviour, interpersonal behaviour, decisive behaviour, ethical orientation, venturing behaviour, enterprising behaviour and learning orientation.

According to Man, Lau and Chan (2008); Noor, Hasliza and Siti, (2010); Aruni, Akira and Hironori, (2014), there are six significant areas of entrepreneurial competencies; they include strategic, commitment, organizing, relationship, conceptual, opportunity competencies. Researchers have investigated different kinds of entrepreneurial competencies, namely, conceptual competency, strategic competency, opportunity competency, learning competency, personal competency, networking competency and ethical competency (Man et al., 2002; Osagie et al., 2016; Yusuff et al., 2016; Stephen et al., 2017; Nakhata, 2018; Quagrainie, 2018; Suhaimi et al., 2018).

The vital role of entrepreneurial competencies attracts researchers, to realize the development of the entrepreneurs' vital capabilities (Khan et al., 2018). Entrepreneurial competencies need to be engaged with a foresight as to the future directions that the firm seeks to explore (Aruni, Akira and Hironori, 2014; Ibidunni, Ogunnaike and Abiodun, 2017). It is really necessary for the SMEs to achieve to improve their entrepreneurial competencies (Sajilan and Tehseen, 2015). Numerous studies have been suggested to measure specific competencies across dissimilar industries and sizes to enhance the generalizability of the competency model (Salah et al., 2015).

\section{ENTREPRENEURIAL ORIENTATION}

Entrepreneurial orientation is one of the most frequently applied firm level constructs in entrepreneurship research (Anderson et al., 2015). This has concerned a substantial interest over the past four decades (Dada and Fogg, 2016; Wales, 2016). Entrepreneurial orientation is a key factor, which is one integrating, building and reconfiguring the external and internal competencies to deal with rapidly changing environments among the small and medium firms (Darwis, 2017).

There has been much debate about the nature of entrepreneurial orientation. The dimensions of entrepreneurial orientation such as innovativeness, Risk-taking, proactiveness, autonomy and competitive aggressiveness are documented in literature (Nwachukwu, Chladkova and Zufan, 2017). In the past, the entrepreneurial orientation role in organizations has been a key area of interest to numerous researchers. Entrepreneurship oriented ventures are innovative, calculated risk-takers, and they proactively achieve markets forward of their competitors (Okeyo, Gathungu, and K'Obonyo, 2016). In the same way, adopting entrepreneurial orientation as a means of a strategic approach through which business managers can act as more proactive, creative and risk-taker that would certainly differentiate them from the market rivals (Hossain \&Asheq, 2019).

There are emerging studies on Entrepreneurial orientation in the literature (Ahmad, et al., 2019). In the same way, entrepreneurial orientation can be considered as a prominent concept in the literature (Wales, 2016; Zahra, Wright and Abdelgawad, 2014). It has received considerable attention in the literature as many studies from various countries have sought to make conceptual and empirical progress in this area (Gupta, and Batra, 2015). Covin and Miller (2014) also stated that entrepreneurial orientation has become one of the most frequently mentioned topics which have been investigated by scholars and practitioners. 
According to Covin and Miller, (2014), entrepreneurial orientation has become one of the most established constructs in entrepreneurship and broader management research, and a number of recent reviews of the entrepreneurial orientation literature have been conducted.

Empirical research has scarcely addressed the role of entrepreneurial orientation in service firms although the service sector has become the growing industry sector (Ahmad, et al., 2019). Research on entrepreneurial orientation in developing countries has not found to be many in numbers, so it needs a lot of research in order to enhance the implementation and adjustment in the concept due to institutional differences (Hughes \& Mustafa, 2016). Similar studies should be conducted possibly in developing countries (Ibrahim \& Abu, 2020). Similarly, Haider, Asad and Fatima (2017) also pointed out that there are limited studies on the association between entrepreneurial orientation and business performance in developing countries.

\section{ENTREPRENEURIAL COMPETENCIES AND PERFORMANCE}

Entrepreneurial competencies are recognized as a unique set of competencies that are linked to the implementation of effective entrepreneurship. Such entrepreneurship is typically related with small and medium enterprises for survival and growth (Carayannopoulos, 2017). For decades, entrepreneurial competencies have been viewed as essential for entrepreneurs to perform successfully and transform businesses (Mohsin et al., 2017). Omar et al. (2016); Tehseen\&Ramayah (2015) claim that the success of any firm depends on several important resources that make entrepreneurial competencies more critical and intangible. These competencies are perceived as the capability to complete a task using the resources that enhance enterprise performance (Al-Mamun et al., 2016). Extant literature shows that entrepreneurial competencies help to create value and develop new businesses (Ogunnaike, Ade-Turton and Ogbari, 2014). Similarly, Nwachukwu, Chladkova and Pavel Zufan, (2017), stated that entrepreneurial competencies are really important for business success and preliminary studies of the connection between entrepreneurial competencies and performance indicate a positive association. Entrepreneurial competencies were valuable and intangible ability for firms to accomplish exceptional performance (Al-Mamun et al., 2016; Tehseen and Ramayah, 2015). To be a successful entrepreneur, development of entrepreneurial competencies is important as they are central to the success of small and medium size organization (Sajeena, 2020).

Numerous studies conducted in various countries recognize that entrepreneurial competencies have a positive impact on business success. It provides empirical proof on the positive effects of entrepreneurial competencies on enterprise success in those countries (Tehseen, 2017; Nasuredin, Halipah, \&Shamsuddin, 2016; Rah-man, Amran, \& Ahmad, 2015). A study carried out by Tanoira and Valencia (2014) in Mexico, showed that entrepreneurial competencies have a positive impact on venture performance. Sajilan\&Tehseen (2015) claimed that entrepreneurial competencies of Malaysian entrepreneurs are significant for the success, survival and development of SMEs in Malaysia. Nasuredin et al., (2016) conducted another research on the association between entrepreneurial competencies and performance of selected Malaysian SMEs. The outcome illustrates that the entrepreneurial competencies increase the performance of firms and enhance the competitive advantage as well in Malaysia. Soejono et al. (2015), confirmed that entrepreneurial competency was a strong predictor of the business success in Australia and Malaysia. Aliyu (2017) investigated Entrepreneurial Competencies and Small and Medium Enterprise performance in Nigeria. Based on the findings, the study concluded that entrepreneurship competencies have a significant effect on the performance of SMEs. Similarly, SME operations can sustain with the aid of a right mix of entrepreneurial competencies in Nigeria (Ibidunni et al., 2017). Nusrat and Tarun (2014) examined the association between entrepreneurial characteristics 
and the SME performance in Khulna. The results of the study confirm that entrepreneurial competencies are needed by entrepreneurs to improve the performance of their businesses.

Some studies have come to inconsistent results and conflicting conclusions about the link between entrepreneurial competencies and business success. Qureshi, Aziz and Mian (2017) revealed that personal competency plays a key role in the success of ventures. Jiang, Yang and Wang (2016) stated that ethical competency plays a key role in success of business. Rahman et al. (2014) showed a positive impact of strategic competency on financial and nonfinancial performance, while finding that technical competence is significantly related only to financial performance. Another study by Rahman et al. (2015) claimed that a significant impact of opportunity and innovative competencies on business performance was significant. Similarly, Nasuredin et al. (2016) reported that strategic and opportunity competencies have a positive impact on the firm success, while conceptual, relationship and commitment competencies do not have a strong impact on business success. Mohsin (2015) discovered that strategic, opportunity and conceptual competencies have a positive impact on success of business. However, technical and relationship competencies are not confirmed for business success. Entrepreneurial competencies such as opportunity, conceptual, strategic and commitment competencies significantly influence the performance of firms (Ibidunni et al., 2018). Ahmad et al. (2018) and Mitchelmore et al. (2014) examined entrepreneurial competencies such as strategic, ethical and network competencies are the vital for internal resources which contribute to the SME growth. Many current studies placed a positive effect of entrepreneurship competencies, especially strategic competency for business success, growth and performance of SMEs (Ahmad, 2007; Irene, 2017; Minimol, 2017; Stephen et al., 2017; Tamyez et al., 2017). Many of recent research have confirmed the positive effect of ethical competency on firm growth (Korsakiene and Diskiene, 2015; Ahmad, 2007; Ahmad et al., 2010; Kaur and Bains, 2013; Man, 2001; Tehseen and Ramayah, 2015; Irene, 2017; Tamyez et al., 2017). Skill competency has a significant impact on the small and medium scale enterprises performance and personality competency also has a significant impact on the small and medium scale enterprises performance (Ango and Margaret, 2018). Han (2016) confirmed that the organizing, strategic and commitment competencies have positively influenced on SME performance. However, no linkage was found between competencies of opportunity, relationship, conceptual competencies with performance of SMEs. Due to Nusrat and Tarun (2014), opportunity, organizing, relationship, and strategic competencies have an important effect on firm performance. Other areas of competency named commitment and conceptual competencies are currently not significant to the performance of business.

The positive influence of entrepreneurial competencies towards business success has been widely debated in the literature (Tehseen, 2017; Farooq \&Abideen, 2015). In general, the results of conceptual studies on entrepreneurial competencies and organizational performance literature show a significant positive correlation (Yusuff et al., 2016; Tehseen and Ramayah, 2015). Many studies have argued that a lack of entrepreneurial competencies impedes success of SMEs (Tehseen and Ramayah, 2015). Entrepreneurial competencies are very critical for the firms' success. Previous studies on the association between entrepreneurial competencies and firm performance propose a positive linkage (Nwachukwu, Chladkova and Zufan, 2017). A review of relevant entrepreneurial competency literature has identified that the most of empirical studies that consider entrepreneurial competencies as a holistic approach have confirmed its significant effect on performance of firms (Kabir et al., 2017). Several studies exist that have linked entrepreneurial competencies with the success and performance of SMEs. Some of these studies revealed that there is a positive and significant influence of entrepreneurial competencies on the performance of SMEs (Barazandeh et al., 2015; Mitchelmore et al., 2014; Sarwoko, Surachman, and Hadiwidjojo, 2013; and Tehseen and 
Ramayah, 2015. Hence, it is sufficient evidence to ascertain that entrepreneurial competencies are vital to the SMEs.

Nevertheless, some previous research studies on the association between entrepreneurial competencies and firm performance have yielded mixed and weak results (Narkhede et al., 2014). Similarly, a study by Lopa\& Bose (2014) showed that entrepreneurial competencies are not significantly related with the firm performance. Thus, the inconsistent results of the studies connected to this relationship, suggest that the association between entrepreneurial competencies and performance of small firm is questionable (Hashim, Raza and Minai, 2018). There are a number of dimensions still need to be tested together as dimensions of entrepreneurial competencies which affecting the performance of small businesses (Hashim, Raza and Minai, 2018). Mitchelmore\& Rowley (2013) stated that there is a necessity for further research on entrepreneurial competencies which are affecting on the performance of small businesses. Furthermore, there is a gap in the knowledge related to entrepreneurial competencies of entrepreneurs (Yusuff et al., 2016). Therefore, further research is needed on the relationship between entrepreneurial competencies and SME performance to explore further (Hashim, Raza \&Minai, 2018).

\section{ENTREPRENEURIAL ORIENTATION AND PERFORMANCE}

The impact of entrepreneurial orientation on performance is consistent with a large number of studies (Monteiro, Soares, and Rua, 2019). Similarly, a number of studies have been conducted on the relationship between entrepreneurial orientation and organizational performance (Jia et al., 2014). Most scholars have found a positive impact of entrepreneurial orientation on firm performance (Covin\& Miller, 2014; Lomberg et al., 2016). Similarly, Lisboa, Skarmeas, and Saridakis, (2016), pointed out that most prior research on entrepreneurial orientation aggregates its features into a gestalt construct to investigate its influence on firm performance. Recently, Ahmad, et al. (2019) stated that previous scholarly studies have concluded the entrepreneurial orientation positively relates to firm performance. Contrary to the common belief that entrepreneurial orientation constantly has a positive effect on firm performance, the effect of entrepreneurial orientation on firm's performance is actually mixed (Okeyo, Gathungu and K'Obonyo, 2016). According to Affendy et al. (2015), entrepreneurial orientation does not significantly influence the business performance among SME. Similarly, Novita, Parawansa, \&Maming (2020) very recently stated that entrepreneurial orientation does not have a positive and no significant effect on business performance.

The ability of innovation of SMEs in producing products can be done if the actors of SMEs have a high entrepreneurial orientation (Sulistyo\&Ayuni, 2020). Adequate entrepreneurial orientation must be intensified by both firm and government to encourage the growth of small and medium scale firms (Igweh, \& Stephen, 2019). In the same way, the role of entrepreneurial orientation leverages business' export performance (Monteiro, Soares\&Rua, 2019). Business would be more successful in achieving their growth and profitability goals if they are entrepreneurially oriented (Oni, Agbobli and Iwu, 2019).

There is consent that entrepreneurial orientation is linked positively to business performance and this correlation is dependent upon many factors (Gupta and Batra, 2015; Lechner and Gudmundsson, 2014). Studies (Covin and Miller, 2014; Tingko and Wenyi, 2017) indicate that entrepreneurial orientation through firms' demonstration of innovativeness, proactiveness, and risk taking significantly impact on organizational performance. This result supports the study (Arshad et al., 2014) which found a correlation between innovativeness, risk taking, proactiveness with business performance. Zhang et al. (2018) exposed that risk taking tendency positively impacts on the innovation performance of the organization. Due to Al-Mamun et al. (2016), propensity to take risks and self-efficacy are entrepreneurial 
components which have a positive influence on the performance of enterprises. Lee et al. (2017) emphasized that proactive managers have the capability to increase the financial performance of their companies. In a current study, Liu and Atuahene-Gima (2018) showed that innovativeness in the marketing field can better forecast the performance of products. Dimitratos et al. (2014) observed that autonomy is a requirement for the growth of enterprise that is used to capture firm level entrepreneurship and related functions. This finding was in line with prevailing studies (Badjuri, 2017; Dimitratos et al., 2014), which confirmed that autonomous actions could improve the performance of micro-enterprises.

According to the recent research, only three attributes such as innovativeness, risk taking and proactiveness influence business performance while no association was found between autonomy and business performance (Oni, Agbobli, and Iwu, 2019). Proactiveness, risktaking and autonomy are positive and significantly related to business performance while, competitiveness was insignificant (Ibrahim \& Abu, 2020). It is very important for SMEs to improve entrepreneurial orientation that includes innovation, proactivity, and risk-taking that are useful for renewing established businesses and increasing competitiveness in the market (Sulistyo\&Ayuni, 2020). According to Hossain \&Asheq (2019), entrepreneurial orientation basically covered five dimensions; risk-taking, innovativeness, proactiveness, competitive aggressiveness as well as autonomy and except for competitive aggressiveness, all dimensions of entrepreneurial orientations possess a positive significant effect on SME performance. To ensure the continuous performance of small and medium enterprises; innovation, pro-activeness, risk-taking and competitive aggressiveness must be sustained (Igweh, \& Stephen, 2019).

The level of entrepreneurial orientation was direct in the dominant part of SMEs in Punjab and there was a noteworthy relationship between innovativeness, pro-activeness, risk taking, and performance of SMEs (Haider, Asad and Fatima, 2017). Jia et al., (2014) conducted a research in entrepreneurial oriented companies in China by examining the association between entrepreneurial orientation and business performance. They explored that entrepreneurial orientation would improve the business performance and a positive impact exists mainly in two dimensions namely innovation and antecedence. Haider et al. (2017) study of entrepreneurial orientation and business performance of manufacturing sector SMEs in Pakistan found a positive association between three entrepreneurial orientation variables innovativeness, proactiveness and risk taking with business performance.

Some researchers have established a positive association between entrepreneurial orientation and firm performance (Jia et al., 2014). According to Buli (2017), for maintaining better performance and longevity of the business firms, the incorporated significance and contributory role of entrepreneurial orientation has not been markedly investigated in the developing countries. Empirical findings show that the relationship between entrepreneurial orientation and organizational performance is unclear and inconclusive (Nwachukwu, Chladkova and Zufan, 2017). The relation between entrepreneurial orientation and firm performance is a worthy area yet for further research, because inconsistencies still exist in empirical studies (Okeyo, Gathungu and K'Obonyo, 2016). Past researches have shown an inconsistency result of the effect of entrepreneurial orientation on organizational performance (Wales, 2016; Bierwerth et al., 2015). The effect of entrepreneurial orientation on firm's performance is inconclusive and is still a subject of academic debate (Okeyo, Gathungu and K'Obonyo, 2016). Ibrahim \& Abu (2020) recently stated that similar studies should be replicated to validate these findings.

\section{CONCLUSION}

Entrepreneurship is the process of creating a new business to produce and market new, innovative or existing product. Entrepreneurship can be considered as a prominent concept in 
the literature. Such entrepreneurship is strategically related with small and medium enterprises for the survival and growth of their business.

Entrepreneurial competencies are recognized as a diverse group of competencies that are related to the effective entrepreneurship. So far, researchers have examined the variety of entrepreneurial competencies such as analytical, commitment, conceptual, decision making, ethical, human, innovative, knowledge, learning, networking, operational, opportunity, organizing, personal, relationship, social responsibility, strategic, technical competencies etc. But, six competencies namely conceptual competency, strategic competency, opportunity competency, learning competency, personal competency, networking competency and ethical competency are well documented in the literature. There are emerging studies on entrepreneurial orientation also in the literature. Entrepreneurial orientation is one of the most commonly applied organizational construct in entrepreneurship research. As per the literature, entrepreneurial orientation is represented by five dimensions such as innovativeness, risk-taking, autonomy, pro-activeness and competitive aggressiveness. But, three dimensions such as innovativeness, risk-taking, pro-activeness are well documented in the literature.

Both entrepreneurial competencies and orientation affect organizational performance as per the literature. Performance of small firms largely depends on the competencies of the entrepreneurs. Inadequate entrepreneurial competencies affect key challengers toward the better performance in small business. Entrepreneurial orientation also directly influences the performance of small enterprises. If the entrepreneurs are entrepreneurially oriented, small business would be more successful in achieving their profitability and growth. Entrepreneurial orientation is essential for entrepreneurs to perform business successfully.

Many countries have explored the effect of entrepreneurship on organizational performance. As per the literature, good entrepreneurial studies are still lacking in developing countries. Entrepreneurship is regarded as one of the key development initiative in any country. Therefore, future research needs to expand the field of entrepreneurship in both developed and developing countries, especially in developing countries.

\section{REFERENCES}

1. Affendy,H.A., Asmat-Nizam, Abdul-Talib, Farid, M.S. (2015). Entrepreneurial Orientation Effects on Market Orientation and SMEs Business Performance - A SEM Approach. Review of Integrative Business \& Economics Research, 4(3), 259- 271.

2. Ahmad, A., Supian, K., Muhammad Yunus, I. F., Tanius, E., \&Ishak, B. (2019). Entrepreneurial Orientation and Hospitality Performance: The Mediating Effect of Market Orientation. International Journal of Accounting, Finance and Business (IJAFB), 4(19), 61-71.

3. Ahmad, N.H. (2007). A Cross cultural study of entrepreneurial competencies and entrepreneurial success in SMEs in Australia and Malaysia, $\mathrm{PhD}$ dissertation, The University of Adelaide, Australia.

4. Ahmad, N.H., Ramayah, T., Wilson, C. \&Kummerow, L. (2010). Is entrepreneurial competency and business success relationship contingent upon business environment? A study of Malaysian SMEs. International Journal of Entrepreneurial Behaviour\& Research, 16(3), 182-203.

5. Ahmad, N.H., Suseno, Y., Seet, P.S., Susomrith, P., \& Rashid, Z. (2018). Entrepreneurial competencies and firm performance in emerging economies: a study of women entrepreneurs in Malaysia, Knowledge, Learning and Innovation, Contributions to Management Science.

6. Aliyu, M. S. (2017). Entrepreneurial Competencies and the Performance of Small and Medium Enterprises (SMEs) in Zaria Local Government Area of Kaduna State. 
International Journal of Entrepreneurial Development, Education and Science Research, 4(2), 116-138.

7. Al-Mamun, A., Saufi, R.A., \& Ismail, M.B. (2016). Human capital, credit, and start-up motives: a study among rural micro-enterprises in Malaysia, The Journal of Developing Areas, 50(4), 383-400.

8. Anderson, B. S., Kreiser, P. M., Kuratko, D. F., Hornsby, J. S., \&Eshima, Y. (2015). Reconceptualising entrepreneurial orientation. Strategic Management Journal, 36, 15791596.

9. Ango, Y., \& Margaret, S. (2018). Impact of Entrepreneurial Competencies on the Performance of Small and Medium Enterprises in Kaduna Metropolis, Nigeria. Online Journal of Arts, Management and Social Sciences (OJAMSS), 3(2), 78 - 90.

10. Arshad, Shafinaz, A., Rasli, A., Arshad, A.A., \& Zain, Z.M. (2014). The impact of entrepreneurial orientation on business performance: A study of technology based SMEs in Malaysia. Procedia-social and BehaviouralSciences, 130, 46-53.

11. Aruni W., Akira K., \& Hironori Y. (2014). Entrepreneurial competencies and entrepreneurial orientation of tea manufacturing firms in Sri Lanka. Asian Social Science, 10(18), 50-62.

12. Bacigalupo, M., Kampylis, P., Punie, Y., Van den Brande, G. (2016). EntreComp: The Entrepreneurship Competence Framework. Luxembourg,Publication Office of the European Union; EUR $27939 \mathrm{EN}$.

13. Badal, S.B. (2014). 10 Talents that drive entrepreneurial success. Entrepreneurial Strengths Finder, Gallup Press.

14. Badjuri, A. (2017), Pengaruhbudayaorganisasi, pengalaman, otonomi, profesionalismedanambiguitasperanterhadapkinerja auditor (Studiempirispada KAP di Jawa Tengah), Students' Journal of Accounting and Banking, 6 (2), 1-15.

15. Bahari, N., Yunus, A. R., \&Jabar, J. (2017). Effective Success Factor of Malaysian SMEs Firm Performance Influence by Entrepreneur Personal Characteristics, Entrepreneurial Orientation and Government Support Program. The Social Sciences, 12(7), 1157-1162.

16. Bamiatzi, V.C., \&Kirchmaier, T. (2014). Strategies for superior performance under adverse conditions: A focus on small and medium-sized high-growth firms. International Small Business Journal, 32(3), 259-284.

17. Barazandeh, M., Parvizian, K., Alizadeh, M., \&Khosravi, S. (2015). Investigating the effect of entrepreneurial competencies on business performance among early stage entrepreneurs Global Entrepreneurship Monitor (GEM 2010 survey data). Journal of Global Entrepreneurship Research, 5(1), 18.

18. Bierwerth, M., Schwens, C., Isidor, R., \&Kabst, R. (2015). Corporate entrepreneurial and performance: A meta-analysis. Small Business Economics, 45(2), 255-278.

19. Boyatzis, R.E. (1982), The Competent Manager: A Model for Effective Performance, John Wiley \& Sons, New York, NY.

20. Buli, B.M. (2017). Entrepreneurial orientation, market orientation and performance of SMEs in the manufacturing industry: Evidence from Ethiopian enterprises. Management Research Review, 40(3), 292-309.

21. Carayannopoulos, S. (2017). Small, young firm flexibility and performance in the context of disruptive innovations. International Journal of Entrepreneurship and Innovation Management, 21(1-2), 105-118.

22. CareerOneStop. (2014). Help and FAQs - Learn About Competency Models. Retrieved from http://www.careeronestop.org/COMPETENCYMODEL/faq.aspx\#modelTool

23. Covin, J. G., \& Miller, D. (2014). International Entrepreneurial Orientation: Conceptual Considerations, Research Themes, Measurement Issues, and Future Research Directions. Entrepreneurship: Theory and Practice, 38(1), 11-44. 
24. Dada, O. and Fogg, E. (2016). Organizational learning, entrepreneurial orientation, and the role of university engagement in SMES. International Small Business Journal 34(1): 86-104.

25. Darwis, G. (2017). Accelerated transformation of Indonesian SME's: embracing entrepreneurial orientation and innovation on achieving dynamic capability to increase competitiveness. $3^{\text {rd }}$ International Indonesian Forum for Asian Studies: Borderless communities and nations with borders, Challenges of Globalizationx, Yogyakarta.

26. Dewi, S., Kasali, R., Balqiah, T.E., \&Widjaja, A.W. (2017). The Role of Entrepreneurial Orientation in Achieving Organization Performance through Business Model Innovation and Strategic Collaboration. 11th International Conference on Business and Management Research (ICBMR 2017), Advances in Economics, Business and Management Research, 36.

27. Dimitratos, P., Liouka, I., \& Young, S. (2014). A missing operationalization: entrepreneurial competencies in multinational enterprise subsidiaries, Long Range Planning, 47(1/2), 64-75.

28. Farooq, W., \&Abideen, Z.U. (2015). SMEs' preparedness to face economic crisis: a proposed framework for Malaysian SMEs, East West Journal of Business and Social Studies, 4(2), 66-79.

29. Gupta, V. K., \&Batra, S. (2015). Entrepreneurial orientation and firm performance in Indian SMEs: Universal and contingency perspectives. International Small Business Journal, 1-23.

30. Haider, S. H., Asad, M., \& Fatima, M. (2017). Entrepreneurial orientation and business performance of manufacturing sector small and medium scale enterprises of Punjab Pakistan. European Business and Management, 3(2), 21-28.

31. Han, M. O. (2016). Determinants of SMES' Performance: the case of Kyaing Tong, Eastern Shan State, Myanmar. Assumption University, Graduate School of Business.

32. Hashim, N.A.B., Raza, S., \&Minai, M.S. (2018). Relationship between entrepreneurial competencies and small firm performance: are dynamic capabilities the missing link. Academy of Strategic Management Journal. 17(2).

33. Hossain, M.U., Asheq, A.A. (2019). The Role of Entrepreneurial Orientation to SME Performance In Bangladesh. International Journal of Entrepreneurship, 23(1).

34. Hughes, M. and Mustafa, M. (2016). Antecedents of Corporate Entrepreneurship in SMEs: Evidence from an Emerging Economy. Journal of Small Business Management, 55(s1), 115-140.

35. Hyder, S. \&Lussier, R.N. (2016). Why businesses succeed or fail: A study on small businesses in Pakistan. Journal of Entrepreneurship in Emerging Economies, 8(1), 82100.

36. Ibidunni, A S., Ogunnaike, O.O., \&Abiodun, A.J. (2017). Extending the knowledge strategy concept: Linking organizational knowledge with strategic orientations. Academy of Strategic Management Journal, 16(3), 1-11.

37. Ibidunni, A.S., Atolagbe, T.M., Obi, J., Olokundun, M.A., Oke, O.A., Amaihian, A.B., Borishade, T.T., and Obaoye D. (2018). Moderating Effect of Entrepreneurial Orientation On Entrepreneurial Competencies and Performance of Agro-Based SMEs. International Journal of Entrepreneurship, 22 (1).

38. Ibidunni, A.S., Olokundun, M.A., Oke, A.O. \&Nwaomonoh, I.C. (2017). Enhancing the performance of agro-based SMES: The role of entrepreneurship competencies. Covenant Journal of Entrepreneurship, 1(1), 44-51.

39. Ibrahim, A.U., \& Abu, M.M. (2020). Influence of Entrepreneurial Orientation on Firms Performance: Evidence from Small and Medium Enterprises in Nigeria. International Journal of Economics and Financial Issues, 10(2), 99-106. 
40. Igweh, F., \& Stephen, A. (2019). Effect of entrepreneurial roles on performance of SMEs: The Nigeria human resource perspective. International Journal of Business, Economics \& Management, 3(1), 22-29.

41. Irene, B.N. (2017). Women entrepreneurship in South Africa: understanding the role of competencies in business success. The Southern African Journal of Entrepreneurship and Small Business Management, 9(1), 1-9.

42. Jia, J., Wang, S., Zhao, X., \& Yu, X. (2014). Exploring the relationship between entrepreneurial orientation and corporate performance: The role of competency of executives in entrepreneurial-oriented corporations. Nankai Business ReviewInternational, 5(3), 326- 344.

43. Jiang, X., Yang, Y., Pei, Y. L., \& Wang, G. (2016). Entrepreneurial orientation, strategic alliances, and firm performance: Inside the black box. Long Range Planning, 49(1), 103116.

44. Kabir, M., Ibrahim, H.I., \& Shah, K.A.M. (2017). Entrepreneurial competency as determinant for success of female entrepreneurs in Nigeria. Indonesian Journal of Business and Entrepreneurship (IJBE), 3(2), 143.

45. Kaur, H., \&Bains, A. (2013). Understanding the concept of entrepreneur competency. Journal of Business Management \& Social Sciences Research (JBM\&SSR), 2(11), 31-33.

46. Khan,G., Ali,M.H., Jantan, A.H.B., \&Latiff, A.R. (2018). Multicultural Study of Entrepreneurial Competencies and SMEs Success in Malaysian Service Industry: A Conceptual Model. Journal of Management Science and Business Intelligence, 44-49.

47. Korsakiene, R., \&Diskiene, D. (2015). Do competencies of entrepreneurs and managers influence internationalization processes? Investigation of Lithuanian SMEs. ECIE2015 10th European Conference on Innovation and Entrepreneurship, 384.

48. Lechner, C., \&Gudmundsson, S.V. (2014). Entrepreneurial orientation, firm strategy and small firm performance. International Small Business Journal, 32(1), 36-60.

49. Lisboa, A., Skarmeas, D., \&Saridakis, C. (2016). Entrepreneurial orientation pathways to performance: A fuzzy-set analysis. Journal of Business Research, 69 (4), 1319-1324. ISSN 0148-2963.

50. Liu, W., \&Atuahene-Gima, K. (2018). Enhancing product innovation performance in a dysfunctional competitive environment: the roles of competitive strategies and marketbased assets. Industrial Marketing Management, 73, 7-20.

51. Lomberg, C., Urbig, D., Stockmann, C., Marino, L. D., \& Dickson, P. H. (2016). Entrepreneurial orientation: The dimensions' shared effects in explaining firm performance. Entrepreneurship Theory and Practice.

52. Lopa, N.Z., \& Bose, T.K. (2014). Relationship between entrepreneurial competencies of SME owners/managers and firm performance: A study on manufacturing SMEs in Khulna city. Journal of Entrepreneurship and Management, 3(3).

53. Man, T. W. Y. (2001). Entrepreneurial Competencies and the Performance of Small and Medium Enterprises in the Hong Kong Services Sector. doctoral dissertation, TheHong Kong Polytechnic University, Hong Kong.

54. Man, T.W.Y., Lau, T. \& Snape, E. (2008). Entrepreneurial competencies and the performance of small and medium enterprises: An investigation through a framework of competitiveness. Journal of Small Business and Entrepreneurship, 23(3), 257-276.

55. Man, Thomas, W.Y., Lau, T., \& Chan, K.F. (2002). The Competitiveness of Small and Medium Enterprises: A Conceptualization with Focus on Entrepreneurial Competencies. Journal of Business Venturing, 17(2), 123-142.

56. Minimol, M.C. (2017). Linkage between entrepreneurial competency and social entrepreneurship: evidences from SMEs in Kerala. Asian Social Science, 13(10), 31-42. 
57. Mitchelmore, S. \& Rowley, J. (2013). Entrepreneurial competencies of women entrepreneurs pursuing business growth. Journal of Small Business and Enterprise Development, 20(1), 125-142.

58. Mitchelmore, S., \& Rowley, J. (2010). Entrepreneurial Competencies: A Literature Review and Development Agenda. International Journal of Entrepreneurial Behaviour andResearch, 16(2), 92-111.

59. Mitchelmore, S., Rowley, J., \&Shiu, E. (2014). Competencies associated with growth of women-led SMEs. Journal of Small Business and Enterprise Development, 21(4), 588601.

60. Mohsin, A. M. A. (2015). The Relationships between Entrepreneurial Attitude Orientation, Market Orientation, Entrepreneurial Competencies, Competitive Intelligence and Innovative Performance. Doctoral dissertation, UniversitiSains Malaysia.

61. Mohsin, A.B.B.A., Halim, H.A., Ahmad, N.H., \&Farhana, N. (2017). Assessing the Role of Entrepreneurial Competencies on Innovation Performance: A Partial Least Squares (PLS) Approach. The Journal of Business Inquiry, 16(1), 88-101.

62. Monteiro, A.P., Soares, A.M. and Rua. O.L. (2019). Linking intangible resources and entrepreneurial orientation to export performance: The mediating effect of dynamic capabilities. Journal of Innovation \& Knowledge, 179-187.

63. Nakhata, C. (2007). The Effects of Human Capital and Entrepreneurial Competencies on the Career Success of SME Entrepreneurs in Thailand, The Business Review, 9 (1), 62-69

64. Nakhata, C. (2018). The relationships between human capital, entrepreneurial competencies and career success of SME entrepreneurs in Thailand. AU Journal of Management, 5(1), 17-26.

65. Narkhede, B.E., Nehete, R.S., Raut, R.D., \& Mahajan, S.K. (2014). Impact of entrepreneurial skills on the firm's performance: Evidence from manufacturing SMEs in India. International Journal of Indian Culture and Business Management, 8(2), 216-236.

66. Nason, R. S., McKelvie, A., \& Lumpkin, G.T. (2015). The role of organizational size in heterogeneous nature of corporate entrepreneurship. Small Business Economics, 45(2), 279-304.

67. Nasuredin, J., Halipah, A.H., \&Shamsudin, A.S. (2016). Entrepreneurial Competency and SMEs Performance in Malaysia: Dynamic Capabilities as Mediator. International Journalof Research, 3(4), 4759-4770.

68. Noor, H.A., Hasliza, A.H., \&Siti, R.M.Z. (2010). Is entrepreneurial competency the silver bullet for SME success in a developing nation? International Business Management, 4(2), 67-75.

69. Novita, L. Parawansa, D.A.S., \&Maming, J. (2020). The Effect of Market Orientation and Enterpreneural Orientation on Business Performance with Marketing Capabilities as a Mediation Variable (Case in Public Bank of Makassar City). Hasanuddin Journal of Applied Business and Entrepreneurship, 3(1).

70. Nusrat Z. L. \&Tarun K. B. (2014). Relationship between Entrepreneurial Competencies of SME Owners/Managers and Firm Performance: A Study on Manufacturing SMEs in Khulna City.

71. Nwachukwu, C., Chladkova, H., \&Zufan, P. (2017). The relationship between entrepreneurial orientation, Entrepreneurial competencies, entrepreneurial Leadership, and firm performance: a proposed model. Business Trends, 7(1), 3-16.

72. Ogunnaike, O.O., Ade-Turton, D., \&Ogbari, M.E. (2014). Higher education marketing: Does corporate quality really matter? Proceedings of the 23rd International Business Information Management Association Conference, 1, 2846-2861. 
73. Okeyo, W.O., Gathungu, J.M. and K'Obonyo, P. (2016). Entrepreneurial Orientation, Business Development Services, Business Environment, and Performance: A Critical Literature Review. European Scientific Journal, 12 (29).

74. Omar, N.A., Aris, H.M., \&Nazri, M.A. (2016). The effect of entrepreneurial orientation, innovation capability and knowledge creation on firm performance: A perspective on small scale entrepreneurs. JurnalPengurusan (UKM Journal of Management), 48.

75. Oni, O., Agbobli, E.K., and Iwu, C.G. (2019). Entrepreneurial Orientation and Performance of Small Business in Vryburg Region North West Province South Africa. Journal of Reviews on Global Economics, 8, 63-71.

76. Osagie, E.R., Wesselink, R., Blok, V., Lans, T., \& Mulder, M. (2016), Individual competencies for corporate social responsibility: a literature and practice perspective. Journal of Business Ethics, 135(2), 233-252.

77. Pofeldt, E. (2014). The 10 qualities of highly successful entrepreneurs. Forbes.

78. Qamruzzaman, M., \&Jianguo, W. (2018). SME financing innovation and SME development in Bangladesh: An application of ARDL. Journal of Small Business \& Entrepreneurship.

79. Quagrainie, F.A. (2018). Family values and practices promoting entrepreneurial competencies among Ghanaian women. International Journal of Entrepreneurship and Small Business, 33(2), 202-219.

80. Qureshi, M. S., Aziz, N., \&Mian, S. A. (2017). How marketing capabilities shape entrepreneurial firm's performance? Evidence from new technology based firms in turkey. Journal of Global Entrepreneurship Research, 7(1), 15.

81. Rahman, M. (2015). Development of tourism industry in Bangladesh: Issues and strategies (Doctoral dissertation).

82. Rahman, S. A., Amran, A., Ahmad, N. H., \& Taghizadeh, S. K. (2015). Supporting entrepreneurial business success at the base of pyramid through entrepreneurial competencies. Management Decision, 53(6), 1203-1223.

83. Rahman, S.A., Amran, A., Ahmad, N.H., \&Taghizadeh, S.K. (2014). Prospective entrepreneurial competencies to ensure subjective wellbeing of the entrepreneurs at the base of pyramid. Proceedings Book of ICBSSS, Malaysia Handbook on Business Strategy and Social Sciences, PAK Publishing Group, 56-64.

84. Rathna, G. K. \&Vijaya, T. G. (2009). Competencies of Entrepreneurs and Intrapreneurs: A Comparative Study. South Asian Journal of Management, 16(2), 28-60.

85. Rauch, J. (2015). Disruptive entrepreneurship is transforming U.S. health care. Center of Effective Public Management, 1-19.

86. Rosli, N.F., \& Abdullah, N. (2015). Comparative study on the determinants on SMEs performances in Selangor and Sabah, Malaysia. Handbook on the Emerging Trends in Scientific Research, 3, 107-111.

87. Sajeena, H. (2020). An Overview of Entrepreneurial Competencies. OUR HERITAGE (UGC Care Journal), 68(55).

88. Sajilan, S., \&Tehseen, S. (2015). Cultural Orientations, Entrepreneurial Competencies, and SMEs Business Success: The Contingent Roles of Environmental Turbulence and Network Competence. Review of Integrative Business \& Economics Research, 4(2), 2035 .

89. Salah, B., Dulys, A., \& Salah, B.I. (2015). Improving self-perception of entrepreneurial competencies among the entrepreneurs: does entrepreneurial accompanying play a major role? study of ReseauEntreprendre case. Specialized Conference of the Euromed Academy of Business, 9, 21-22. 
90. Sarwoko, E., Surachman, A., \&Hadiwidjojo, D. (2013). Entrepreneurial characteristics and competency as determinants of business performance in SMEs. International Organization of Scientific Research Journal of Business and Management, 7(3), 31-38.

91. Soejono, F., Mendari, A. S., \&Rinamurti, M. (2015). Competency, Entrepreneur Characteristic and Business Performance: Study of The Pempek Business in Palembang. Journal of Indonesian Economy and Business, 30, 30-41.

92. Spencer, L.M. and Spencer, S.M. (1993) Competence at Work: Models for Superior Performance. John Wiley \& Sons, New York.

93. Stephen, I.A., Ayodele, O.M., Oluremi, O.A., \&Ifeoma, N.C. (2017). Enhancing the performance of agro-based SMES: the role of entrepreneurship competencies. Covenant Journal of Entrepreneurship, 1(1), 44-51.

94. Suhaimi, N.H.B.M., Al Mamun, A., Zainol, N.R., \&Nawi, N. (2018). The moderating effect of a supportive environment toward the relationship of entrepreneurial competencies and the performance of informal women entrepreneurs in Kelantan, Malaysia. The Journal of Developing Areas, 52(1), 251-259.

95. Sulistyo, H. \&Ayuni, S. (2020). Competitive advantages of SMEs: The roles of innovation capability, entrepreneurial orientation, and social capital. Contaduría y Administración, 65(1), 1-18.

96. Tamyez, P.F., Ishak, N., Ali, J., \& Omar, S. (2017). Entrepreneurial competencies and networks in the construction industry. International Journal of Applied Engineering Research, 12(23), 13374-13380.

97. Tanoira, F. G. B., \& Valencia, R. A. S. (2014). Knowledge Management, Entrepreneurial Competencies and Organizational Development in Micro and Small Enterprises in Rural Regions in The State of Yucatan, Mexico. European Scientific Journal, ESJ, 10(1).

98. Tehseen, S., \&Ramayah, T. (2015). Entrepreneurial competencies and SMEs business success: The contingent role of external integration. Mediterranean Journal of Social Sciences, 6(1), 50-61.

99. Tehseen. (2017). Cultural orientations, entrepreneurial competencies, Entrepreneurial innovativeness and business success: A comparative study among Malaysian ethnic entrepreneurs in wholesale and retail SMEs. (Doctoral Dissertation). Universiti Kuala lumpur.

100. Tingko, L., \&Wenyi, C. (2017). The relationship between entrepreneurial orientation and firm performance: Influence of family governance. Journal of Family Business Strategy, 8 (1) 213-223.

101. Wales, W.J. (2016). Entrepreneurial orientation: A review and synthesis of promising research directions. International Small Business Journal, 34(1), 3-15.

102. Yusuff, Y.Z.M., Bakar, A.A. \& Ahmad, S. (2016). Determinant factors of women entrepreneurs' business performance: A conceptual Framework. Journal of Global Business and Social Entrepreneurship (GBSE), 1(1), 55-67.

103. Zahra, S.A., Wright, M., \&Abdelgawad, S.G. (2014). Contextualization and the advancement of entrepreneurship research. International Small Business Journal, 32(5), 479-500.

104. Zhang, F., Yang, J., Xu, Z., \& Zhu, G. (2018). Large shareholder participation behaviors, managers' risk-taking, and firm innovation performance: a shareholder activism perspective. Nankai Business Review International, 9(1), 99-115.

105. Zwemstra, J. (2006). Differentiating between Entrepreneurs and Intrapreneurs: A Competency Approach. (Masters in Industrial Psychology), Erasmus UniversityRotterdam, Rotterdam, Netherlands. 